\title{
Meningkatkan Orientasi Masa Depan Remaja Bidang Pendidikan Melalui Pelatihan Fasilitator Masyarakat Gunungkidul
}

\author{
Novia Fetri Aliza1 \\ 1. Program Studi Pendidikan Agama Islam, Fakultas Agama Islam, Universitas Muhammadiyah Yogyakarta \\ Gedung F6 Il. Brawijaya, Geblagan, Tamantirto, Kec. Kasihan, Bantul, Yogyakarta \\ Email: aliza@umy.ac.id \\ DOI: $10.18196 / p p m .34 .288$
}

\begin{abstract}
Abstrak
Pendampingan yang dilakukan dalam pemberdayaan masyarakat ini membahas tentang manfaat pelatihan masyarakat sebagai fasilitator untuk meningkatkan orientasi masa depan remaja bidang Pendidikan di dusun Pule kecamatan Saptosari Gunungkidul Yogyakarta. Adapun faktor yang melatar belakangi dilakukan pendampingan ini adalah terdapatnya remaja yang putus sekolah dan rendahnya minat remaja di dusun pule untuk melanjutkan Pendidikan ke jenjang yang lebih tinggi. Akibat dari rendahnya orientasi masa depan remaja bidang Pendidikan ini menjadikan dusun Pule mengalami kesulitan untuk memelihara fasilitas yang sudah disediakan pemirintah dan LSM untuk meningkatkan kesejahteraan warga, serta warga dusun Pule juga kesulitan mengelola Sumber Daya Alam yang ada. Metode pendampingan yang dilakukan berupa pelatihan untuk anggota masyarakat supaya mampu menjadi fasilitator dalam mendampingi remaja yang ada di dusun Pule untuk meningkatkan orientasi masa depan bidang Pendidikan. Pelatihan fasilitator masyarakat ini dilakukan selama 2 sesi. Hasil dari pelatihan fasilitator ini adalah sudah mulai terlihat adanya perubahan maind set masyarakat tentang arti pentingnya Pendidikan, remaja yang putus sekolah dan tidak melanjutkan sekolah ke jenjang Pendidikan yang lebih tinggi mulai berkurang terutama selama masa follow up menurun hingga zo\%, selain itu warga juga sudah mulai serius mendorong remaja untuk melanjutkan Pendidikan dan merasa kekhawatiran bila ada orangtua yang berdiam diri menyaksikan anaknya memilih untuk tidak melanjutkan sekolah.
\end{abstract}

Kata kunci : Orientasi Masa depan, Remaja, Fasilitator Masyarakat

\section{Pendahuluan}

Remaja di dusun Pule belum memiliki orientasi masa depan yang jelas terutama bidang pendidikan, sehingga remaja masih ada yang putus sekolah di jenjang SD dan SMP. Berdasarkan hasil wawancara yang dilakukan ke salah satu wakil kepala sekolah di SMP yang ada di sekitar dusun Pule menyebutkan bahwa lebih dari $40 \%$ siswa yang menamatkan SMP di sekolah tersebut memilih untuk berhenti sekolah dengan berbagai macam alasan. Berdasarkan hasil observasi ditemukan remaja yang memliki orientasi melanjutkan sekolah ke jenjang yang lebih tinggi yaitu perguruan tinggi kurang dari 5\%. Bahkan masih ditemukan remaja di dusun Pule telah menikah menjelang usia 15 tahun. Faktor ini menjadi siklus yang terulang dari generasi ke generasi, masyarakat dusun Pule mengaku kesulitan dalam bidang perekonomian karena minimnya kemampuan dan pengetahuan mengelola sumberdaya yang ada. Hurluck menyebutkan bahwa masa remaja merupakan masa yang penting karena merupakan penentu di masa depan, sehingga apabila remaja melewatkan fase ini dengan hal-hal yang kurang produktif maka remaja akan kehilangan kesempatan untuk mempersiapkan masa depannya dengan lebih baik. Sistuasi inilah yang menjadi fokus pendampingan masyarakat di dusun Pule karena pembangunan sumber daya manusia terutama generasi muda menentukan keberlanjutan dan kualitas kehidupan masyarakat dusun Pule di masa yang akan datang.

Pembangunan sumberdaya manusia ini adalah faktor kunci yang utama dalam pembangunan dan meningkatkan kesejahteraan masyarakat Pule. Salah satu metode membangun Sumberdaya Manusia adalah melalui Jalur pendidikan baik formal maupun non formal terutama pendidikan di kalangan generasi muda yang akan berperan sebagai pelanjut generasi. Masyarakat perlu ditingkatkan kesadarannya dari semua lapisan yang berlangsung terus menerus untuk bersemangat melanjutkan dan menopang generasi muda untuk bersekolah, sehingga diperlukan "orang dalam" yang berasal dari lingkungan masyarakat Pule yang berperan aktif dalam mewujudkan peningkatan SDM masyarakat Pule. 
Menciptakan Pendamping/Fasilitator Masyarakat yang terlatih yang berasal dari kalangan masyarakat sendiri menjadi sasaran utama dalam program pengabdian ini melalui pelatihan pendamping masyarakat untuk meningkatkan orientasi masa depan remaja. Pendamping masyarakat ini merupakan salah satu langkah untuk membantu masyarakat Pule untuk merancang masa depan yang lebih baik, karena dengan tingginya orientasi Pendidikan remaja diharapkan pola berfikir dari generasi ke generasi mulai membaik dan mereka mulai memilki kemandirian dalam mengelola Sumberdaya yang ada di dusun Pule.

\section{Metode Pelaksanaan}

Program pendampingan terhadap masyarakat ini dilaksanakan dengan metode pelatihan terhadap beberapa orang key person yang ada dalam masyarakat untuk dilatih menjadi fasilitator masyarakat. Proses pelatihannya dilaksanakan dengan bantuan trainer yang fokus pada remaja dan Pendidikan serta psikolog yang memahami metode konseling berfokus solusi. Setiap kelompok masyarakat akan mendapatkan konseling kelompok dengan fokus komunikasi dan Pendidikan remaja serta pentingnya peran masyarakat dalam meningkatkan orientasi remaja di bidang Pendidikan.

Responden atau peserta yang menjadi sasaran dala program pendapingan ini dipilih berdasarkan rekomendasi dari dukuh dan hasil observasi mahasiswa kkn selama satu pekan berdasarkan kriteria yang dibutuhkan dala pendapingan remaja. Adapun kriterianya adalah, orang-orang yang memiliki pengaruh di lingkungan masyarakat, yang dihormati, memiliki kepudulian terhadap pendidikan serta mampu berkomunikasi dengan cukup baik. Dari 20 orang calon responden yang terpilih dan bersedia mengikuti progra pendapingan berjumlah 15 orang.

Adapun perlengkapan yang dubthkan dala progrram pendapingan masyarakat ini adalah microfon/engeras suara, LCD proyektor, modul sederhana yang berisi panduan tentang teknik berkomunikasi efektif, tali rapia untuk ice breaking. Semua perlengkapan yang dubutuhkan dalam program pendapingan ini disediakan sebelum pelaksanaan berlangsung dan telah dibagikan ketika peserta memasuki ruangan yang telah disediakan.

\section{Hasil dan Pembahasan}

Sebelum program pendampingan masyarakat ini dilakukan, maka yang pertama sekali dilaksanakan adalah memberikan arahan kepada sepuluh orang mahasiswa KKN yang terlibat dalam pelaksanaan program ini. Peran mahasiswa dibagi menjadi beberapa bagian, yaitu co fasiliator, bagian konsumsi, dan dokumentasi. Mahasiswa yang berperan sebagai co fasilitator bertugas memandu peserta untuk melakukan latihan-latihan yang dilatihkan oleh fasilitator, sehingga sebelum dilaksanakan langsung kepada masyarakat fasilitator melatih co fasilitator terlebih dahulu.

Program pengabdian ini dilaksana selama dua sesi, pada pertama dipandu oleh instruktur yang difokuskan pada pembahasan motivasi dalam Pendidikan anak remaja sedangkan pada sesi ke dua fokus pada pelatihan dalam mendampingi remaja untuk meningkatkan orientasi Pendidikan di bidang Pendidikan. Peserta yang hadir dalam program ini berjumlah 15 orang terdiri dari laki-laki ataupun perempuan, meskipun undangan diberikan kepada 25 orang peserta yang dipilih berdasarkan peran mereka selama ini dusun pule, yaitu orang-orang yang cukup disegani di dusun pule serta yang memiliki kepedulian terhadap kemajuan dusun Pule. Pada acara pembukaan di hari pertama program pendampingan dilaksanakan di balai desa dan dibuka oleh kepada dukuh dusun Pule Desa Ngloro. 


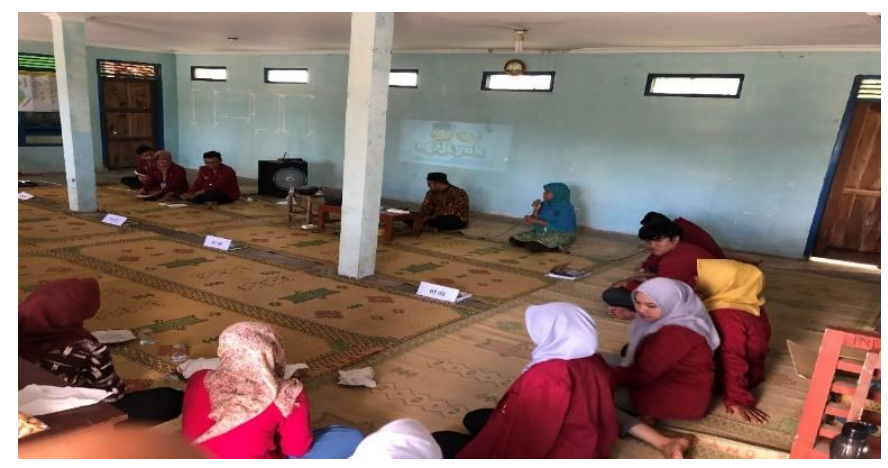

Gambar 1. Pembukaan acara oleh kepala Dukuh

Pada sesi pertama dalam program ini diawali ice breaking, tujuannya adalah untuk membangun kedekatan antara fasilotator dengan peserta, kemudian dilanjutkan dengan diskusi kelompok. Semua peserta dibagi menjadi 3 kelompok masing-masing kelompok didamping oleh satu orang co fasilitator. Pada saat diskusi kelompok ini topik pembahasan di fokukan pada bagaimana peserta memandang arti penting remaja dalam kemajuan dusun pule, bagaimana peserta memandang semangat belajarnya remaja di dusun pule, bagaimana dukungan orangtua terhadap remaja dalam rangka melanjutkan Pendidikan ke jenjang yang lebih tinggi. Setelah selesai melaksanakan diskusi kecil peserta kembali di gabungkan dalam kelompok besar dan hasil disikusi dalam kelompok kecil ini di diskusikan dalam kelompok besar yang dipandu oleh fasilitator.

Hasil dari diskusi kelompok kecil ini adalah peserta menyadari beberapa remaja di dusun pule memiliki minat terhadap Pendidikan cukup rendah, namun bila dibandingkan dengan tahun-tahun sebelumnya minat remaja cukup berkembang. Banyak kendala yang dihadapi oleh remaja dalam melanjutkan pendidikannya, salah satunya adalah rendahnya perekonimian masyarakat di dusun pule menjadikan remaja memiliki keinginan yang tinggi untuk segera bekerja dan memiliki uang/penghasilan sendiri. Hal ini menjadikan remaja kurang antusias mengikuti proses belajar terutama melanjutkan ke jenjang yang lebih tinggi, karena biaya yang dikeluarkan cukup besar, akses yang jauh serta dorongan yang besar dari dalam diri remaja untuk dapat mengikuti gaya hidup yang semakin hedonis seperti memiliki handphone yang baru, memiliki kendaraan sendiri dan lain-lain. Dukungan dari keluarga terhadap remaja juga cukup rendah, karena mayoritas yang menjadi orangtua di dusun pule juga berasal dari latar Pendidikan yang rendah bahkan ada yang tidak mengecap Pendidikan di sekolah formal. Selanjutnya kondisi masyarakat yang seperti ini perlu diberikan kembali penyuluhan tentang arti penting Pendidikan bagi masa depan anak remja secara personal dan kemajuan dusun pule secara umum.

Pada sesi ke dua pendampingan ini diberikan penyuluhan kepada peserta tentang arti pentingnya Pendidikan. Tujuannya adalah untuk memberikan wawasan yang lebih luas lagi kepada masyarakat Dusun Pule tentang bagaimana pentingnya pendidikan. Kegiatan ini juga bertujuan untuk memberikan semangat serta motivasi bagi orang tua serta putra-putri nya agar punya keinginan untuk melanjutkan pendidikan ke jenjang yang lebih tinggi. Proses penyuluhan ini berlangsung sekitar 60 menit, diawali dengan potret remaja masa kini, pandangan Islam terhadap remaja, factor resiko rendahnya Pendidikan remaja dan pentingnya peran keluarga serta dukungan lingkungan dalam orientasi masa depan remaja yang ditutup dengan tanya jawab. Berikut foto pelaksnaan pendampingan pada saat penyuluhan 


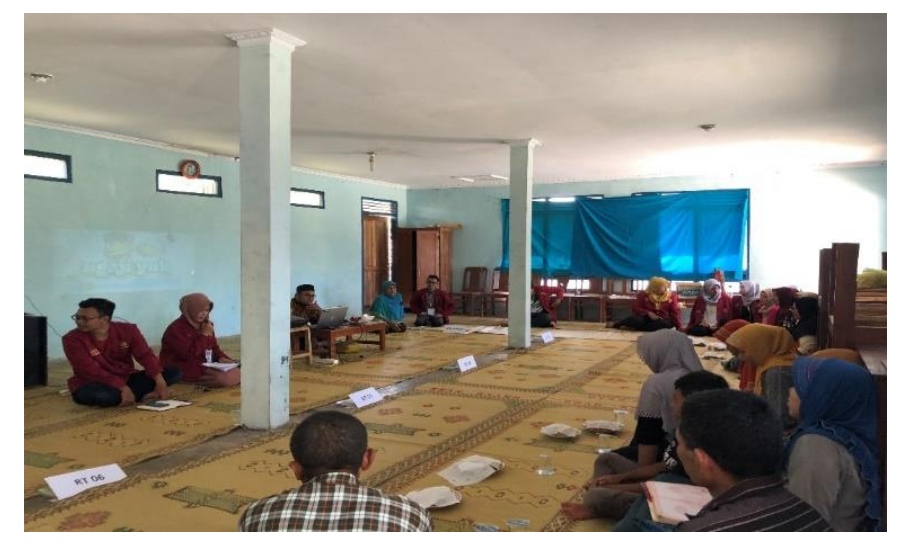

Gambar 2. Penyuluhan pentingnya dukungan orangtua untuk pendidikan bagi remaja

Hasil dari diskusi dengan peserta pada saat penyuluhan ini mulai terlihat bahwa mereka mulai memiliki kesadaran untuk berberan dalam meningkatkan orientasi masa depan remaja di bidang pendiidkan. Dari 15 orang peserta sebelum penyuluhan di mulai ditanyakan siapa yang sudah berperan dalam mendorong remaja untuk terus melanjutkan sekolah hanya setengahnya saja yang sudah melakukan,, namun diakhir sesi semua peserta mengaku ingin sekali berperan dalam mendorong remaja di lingkungannya untuk melanjutkan Pendidikan.

Berdasarkan laporan dari beberapa orang warga masyarakat di dusun Pule, setelah mendapatkan pelatihan beberapa pejabat RT sudah mulai memasukkan Pendidikan remaja dalam pembicaraan keseharian dengan warganya. Selain itu juga ada beberapa orangtua yang menghubungi fasilitator terkait informasi beasiswa untuk anak remaja mereka dalam melanjutkan Pendidikan ke jenjang yang lebih tinggi. Terkait hal ini fasilitator menyarankan menemui seorang tokoh masyarakat di kota monosari untuk menjadi orangtua asuh.

Pada hari ke dua pelaksnaan program pendampingan ini kembali dimulai dengan keceriaan peserta dengan senam Bersama, ice breaking dan dilanjutkan dengan diskusi kelompok kecil. Diskusi kelompok kecil membahas tentang kekuatan dan kelemahan masyarakat pule dalam meningkatkan orientasi masa depan remaja. Pada sesi ketiga dalam program pendampingan ini peserta terlihat antusias dalam mengemukakan keluhan-keluhan serta kelebihan yang dimiliki oleh masyarakat pule. Setelah selesai diskusi dengan kelompok kecil program dilanjutkan dengan membahas hasil diskusi kelompok kecil tersebut dalam kelompok besar yang dipandu oleh fasilitator. Pasa hari ke dua ini fasilitator adalah psikolog yang sudah memiliki pengalaman dalam mendampingi orangtua dan remaja serta cukup konsen dalam aspek Pendidikan.

Pada sesi ke empat fasilitator memberikan pelatihan kepada peserta dalam menghadapi remaja dan Teknik berkomunikasi dengan remaja, karena remaja adalah individu yang unik sehingga diperlukan keterampilan khusus dalam menhadapinya. Pada saat menyampaikan materi peserta terlihat kurang bersemangat dan menginterupsi fasilitator ketika merasa penjelasan fasilitator kurang sesuai dengan nilai-nilai yang dianut masyarakat selama ini. namun setelah mendapatkan penjelasan yang lebih komprehensif peserta memahami, dan mendapatkan insight tentang kekeliruan berfikir yang selama ini mereka pertahankan. Masyarakat meyakini bahwa Pendidikan adalah salah satu gerbang menuju kesuksesan anak-anak mereka, namun mereka merasa tidak perlu melakukan komunikasi yang atraktif dalam rangka memotivasi remaja dalam melanjutkan Pendidikan karena selama ini yang mereka lakukan adalah mengikuti kemauan anak, bila anak-anak mau melanjutkan sekolah mereka akan mendukung akan tetapi kalua anak remaja mereka tidak mau atau malas untuk melanjutkan sekolah orangtua juga tidak perlu memaksa. 


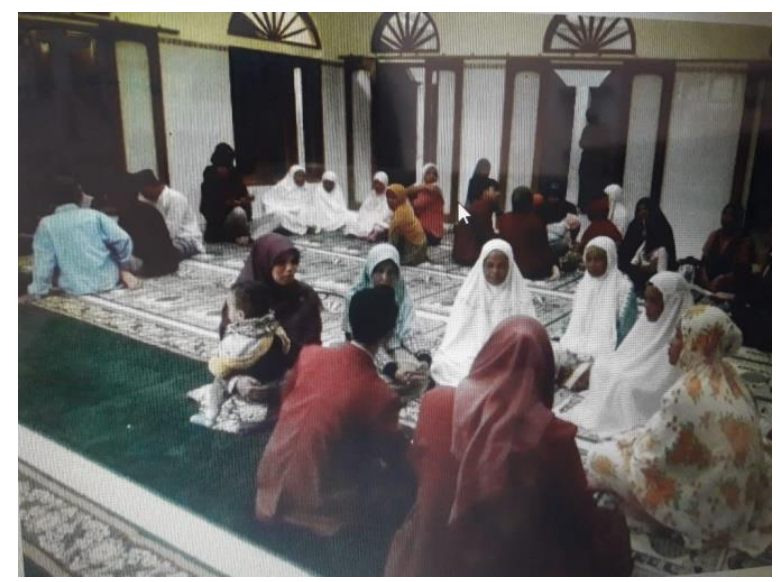

Gambar 3. Diskusi kelompok kecil dan pelaksanaan role play

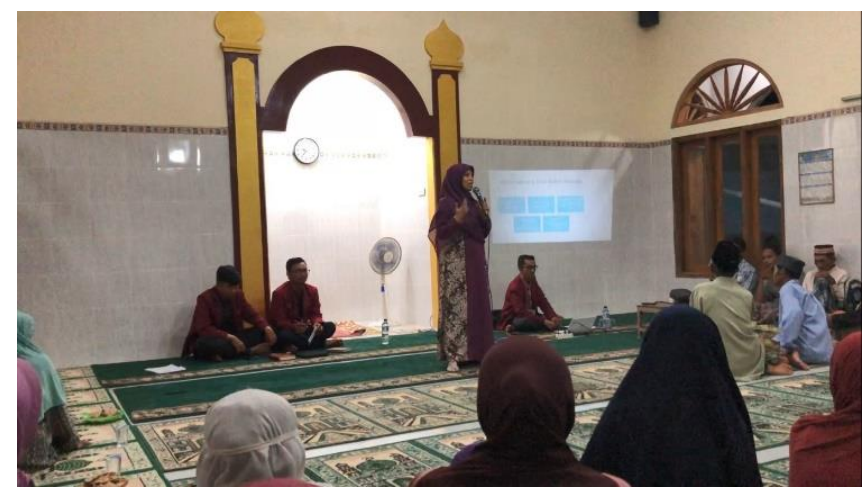

Gambar 4. Pelaksanaan pelatihan fasilitator masyarakat

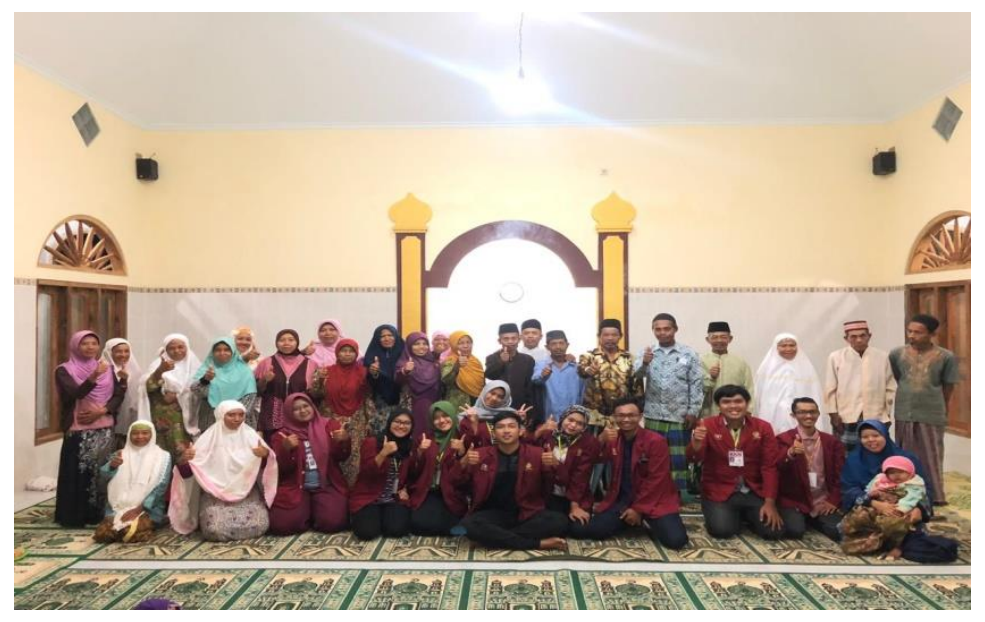

Gambar 5. Akhir sesi pelatihan Fasilitator selama dua hari

Pada sesi ke empat ini juga dilaksanakan role play dalam berkomunikasi dengan remaja, bagaimana cara memotivasi remaja, Teknik bertanya dan menyimak, membantu remaja merumuskan goal setting untuk masa depan. Role play ini dilakukan dengan meminta salah seorang peserta menjadi relawan sebagai orangtua dan salah satu mahasiswa sebagai anak remaja. Selanjutnya peserta diminta berpasangan dengan peserta yang duduk di sebelahnya untuk bermain peras, satu orang menjadi orangtua dan satu orang berperan sebagai anak remaja yang tidak memiliki motivasi melanjutkan pendidikannya. Meskipun diiringi dengan gelak tawa, akan tetapi pelaksanaan role play ini dapat dilaksanakan dengan cukup baik. 
Pada sesi terakhir dilakukan evaluasi terhadap kemampuan peserta dalam memahami dan menyerap proses pendampingan yang telah dilaksanakan. Kemudian dilaksanakan terminasi pada saat pendaftaran siswa baru pada tahun ajaran 2019/2020 apakah terjadi peningkatan kesadaran masyarakat dan jumlah remaja yang melanjutkan Pendidikan ke jenjang yang lebih tinggi.

Berdasarkan informasi yang didapatkan dari pejabat dukuh di dusun Pule ini, secara umum siswa yang lulus SMP tahun ini melanjutkan Pendidikan ke jenjang yang lebih tinggi, tidak ada yang menikah muda, meskipun di tahun sebelumnya juga secara umum sudah banyak yang melanjutkan Pendidikan ke jenjang yang lebih tinggi namun beberapa orang tetap putus sekolah karena berbagai alasan. Pendampingan yang dilakukan oleh beberpa pendamping masyarakat yang telah dilatih dalam program ini diharapkan mampu meminimalisir remaja yang putus sekolah di jenjang sekolah menengah atas. Sesuai dengan penelitian yang dilakukan oleh Nurahmantullah (2016) Orientasi masa depan remaja bidang pendidikan memiliki hubungan yang sangat signifikan dengan dukungan orang tua dan dukungan dari lingkungan tempat tinggal mereka, sehingga semakin tinggi dukungan untuk remaja untuk melajutkan pendidikan ya ke jenjang yang lebih tinggi maka akan semakin tinggi peluang remaja melanjutkan pendidikan ke jenjang yang lebih tinggi.

\section{Simpulan}

Masyarakat dusun Pule yang dipilih untuk menjadi fasilitator masyarakat ini mulai memiliki perubahan mind set terkait peran yang perlu mereka jalankan dalam meningkatkan orientasi masa depan remaja di bidang Pendidikan. Peserta menyadari bahwa kewajiban mereka tidak hanya peduli terhadap anak-anak mereka secara biologis, akan tetapi juga terhadap anakanak remaja yang lainnya. Selain itu peserta juga menyampaikan bahwa keterampilan yang didapatkan dalam pelatihan pada saat pelaksanakan program ini cukup membantu mereka dalam melakukan komunikasi dengan remaja.

\section{Ucapan Terima Kasih}

Program pemberdayaan masyarakat ini dapat terlaksana karena bantuan dari berbagai pihak, sehingga ucapan terimakasih yang mendalam kami sapaikan kepada Universitas Muhammadiyah Yogyakarta (UMY) yang telah memberikan support dana sehingga program ini dapat terlaksana dengan optimal. Berikutnya ucapan terimakasih juga kai sapaikan kepada pejabat Desa Ngloro dan jajarannya khususnya kepada Dusun Pule, serta kepada mahasiswa yang kami banggakan kelompok KKN 22 di Dusun Pule.

\section{Daftar Pustaka}

Djafar, A., Noviekayati, I., \& Saragih, S. (2018). Perbedaan Adversity Quotient dan Kematangan Emosi Remaja SMP ditinjau dari Jenis Kelamin. Journal Psikogenesis, 6(1), 6168. https://doi.org/10.24854/jps.v6i1.633

Fitri, E., Zola, N., \& Ifdil, I. (2018). Profil Kepercayaan Diri Remaja serta Faktor-Faktor yang Mempengaruhi. JPPI (Jurnal Penelitian Pendidikan Indonesia), 4(1), 1. https://doi.org/10.29210/02017182

Handitya, B., \& Ngudiwaluyo, U. (2018). Peran Pendidikan Dalam Membangun Moral Bangsa Di Era Disrupsi. 12.

Nurrahmatullah, M. 2016. Hubungan OMD Remaja Bidang Pendidikan dengan Dukungan Orangtua. Jurnalpsikologi. Universitas Mulawarman 